\title{
TEACHING STUDENTS TO DEVELOP PARAGRAPHS BY POETRY WRITING
}

\author{
Murni Mahmud \\ Faculty of Languages and Literature \\ State University of Makassar, Indonesia \\ Email:murnimahmud@unm.ac.id
}

\begin{abstract}
The use of literary work such as poetry, prose, or drama in English language teaching is recognized as powerful media to teach English language skills. This is commonly known as creative writing, which has recently become important subject in English language teaching. This study had examined the use of English poetry writing in English language teaching, particularly in teaching English writing skills. There are two main points of discussion in this paper, namely the analysis of the students' ability to write poetry in English and the effectiveness of that poetry writing in teaching English writing skills. The study was conducted at the third semester students majoring in English Education at the State University of Makassar, Indonesia. To find data about students' ability in poetry writing, a test was given and the results were analyzed descriptively. To find data about the effectiveness of poetry writing in teaching English writing skills, a quasi-experimental design with a t-test was employed. Findings reveal the students' good ability in writing poetry in English. Aspects of poetry such as imagery, rhyme, rhythm, and sound devices can be seen in the poetry written by students. Poetry writing also has an effective function in teaching English, particularly in developing students' writing skills. Poetry made by the students can invite more ideas to write. Students taught to write poetry in English and asked to develop writing based on that written poetry demonstrate better achievement than those who were not taught by poetry writing.
\end{abstract}

Keywords: poetry, poetry writing, creative writing, English language teaching

\section{INTRODUCTION}

The importance of English as an international language is admitted worldwide, as a means of science and technology. Along with these interests, teaching English at various levels also are required to further advance in order to meet the needs. English teaching should be supported by the accessibility of adequate learning facilities, and more effective learning outcomes and its efficiency in order to achieve better results in English language teaching. These phenomena are also experienced in Indonesia, where English is taught a second language.

One of the English language skills which needs more concerns is writing. This is because writing is considered as a difficult skill, and therefore, the teaching of writing needs more specific strategies. In writing, for example, Alter and Adkin (2006, p. 337) found that students have inadequate skills in writing. A study by Vasquez in Columbia (2008) proves the so many types of errors made by the students in writing composition. Maros, Hua, and Salehuddin (2007) also proved the difficulty faced by the students in using correct English grammar in their writing.

Studies on how to increase students' writing skills had also been conducted. Kim and Yoon (2014), for example, had explored the use of L1 as a strategy in teaching writing. Kim and Yoon (2014, p. 30) stated that "thinking in the L1 during the process of idea generation will make it easier for students to get closer to translating into the L2". Yusof (2008) has also conducted a study on the use of e-learning and found that the internet usage is effective in writing. She stated that "the processes involved in the writing of poetry 
using e-methods have shown that utilizing computer technology and the internet complement, rather than hamper, the creativity of the students" (p. 147). The findings from these studies imply that the teaching of writing needs qualified strategies and need to employ good facilities.

This paper highlights the important use of poetry as one of literary works in English Language Teaching, particularly in teaching writing skills. This is commonly known as creative writing. Dawson (2005) states that creative writing is "a synonym for literature", and usually used for published works of fiction, poetry and drama. Dawson (2005) furthermore explains that creative writing usually refers to a subject or course of study in which students produce writing which is generally considered 'creative'; that is, writing in the aforementioned literary genres.

In this paper, I focus my discussion on two main problems. The first one is the capability of the students in poetry writing and the second one is the effectiveness of poetry writing in teaching writing, particularly in developing paragraphs. Therefore, I first focus this paper to explore the capability of the students in writing poetry in English by observing the characteristics of poetry such as themes, sound devices, rhythm, and imagery. Then, I focus to examine the effectiveness of poetry that had been written by the students as a medium in teaching writing skills (developing ideas in paragraphs).

This study has a prominent contribution to English Language Teaching as a whole. Nowadays, it is expected that teachers or lecturers provide useful and interesting strategies and media in teaching English. Poetry as a form of literary work will become an alternative way for this. Results of this study will be very useful for English language teaching in general and teaching of literature in particular as well as the teaching of writing. This will provide a very useful contribution to the teaching of language and literature, increasing the creativity in teaching English, and also foster students' creativity through literature studies. In addition, the results prove the significant contribution of creative writing as one subject in teaching language skills.

\section{REVIEW OF LITERATURE Creative Writing}

Creative writing is actually a new field in language development. It is relatively new but has been rapidly expanding in the US, the UK, and elsewhere. Nowadays, scholars start to teach creative writing as an academic discipline (Swander, Leahy, \& Cantrell, 2007).

The term creative writing should be related to the term creativity. Dawson (2005) designates creativity as "the ability to create; to produce something new and original, to provide innovative changes to anything which is routine or mechanistic". Therefore, the products of that creativity are "the unique expression of each individual, without any association with the senses and their capacity to fool the mind" (Dawson, 2005). Dawson (2005) further states that in schools creative writing is often described as the free expression of a child's personality, the verbal enunciation of their individual.

An important idea for this creative writing is the power of imagination. Dawson (2005) states that the mental ability to reproduce images previously apprehended by the senses. It was also the part of the mind capable of producing wild, irrational ideas or images with no corresponding object in reality, and of inducing delusion by tricking the senses. By having imagination, creativity may be resulted. Chapple (cited in Dawson, 2005) mentioned that 'creative writing' is 'that written expression in which children put down their own ideas, thoughts, feelings and impressions in their own words. Subramanian (2003) stated that "creative writing promotes the learners' sensitivity and interpretative skills through the exploitation of language awareness 'from the inside", 
This can be seen in poetry writing, which allows the creativity through the power of imagination. Allowing people to express their imagination is a power for the creativity. Dawson (2005) states that creative power was the capacity of a poet's imagination to mimic the divine act of creation by producing in fiction characters which did not exist in nature, or events and ideas which had not previously been contemplated. Poetry writing allows students to express themselves in other way that no other genre does. Something really meaningful and powerful can be written in a much shorter space and time than a report, a narrative, or essay may take. Poetry writing also allows students to play with new vocabulary in a way than other genres do not. Poetry writing activities can be immensely satisfying for students precisely because they can express themselves at a much deeper level than in other writing activities (Harmer, 2004, p. 69).

\section{Literature in Language Teaching}

As discussed in the previous part, it can be inferred that creative writing is actually an act of writing not for professional or academic purposes, but enjoyment and self expression. For that purpose, creative writing usually employs a form of literature such as prose, poetry, or drama. The focus of creative writing is on producing the work of literature, such as poetry writing, or prose writing and then employed those works to produce other pieces of writing. In that way, creative writing is considered effective in developing the ideas of the learners which then support the learners' productive skills.

This fact leads to the point that literature is an effective medium in teaching language skills. Literature which is defines as "writings that are valued as works of art especially fiction drama and poetry in contrast with technical books and newspapers, magazines" (Hornby \& Crowther, 1995, p. 687), proved to be effective in teaching language skills. In fact, many scholar had proved the significant effect of literature in language teaching (Sivapalan \& Subramanan, 2008; Dhillon \& Mogan, 2014). Most of these studies found that although literature is considered as a difficult subject, some of the works of literature can be used to enhance students' language skills. Along with these opinions, Turker (1991) also states that using literary texts very helpful for the students to acquire or learn, how language works in real contexts.

Subramaniam (2003) mentions some benefits of studying literature in language studies as the tool in inviting pleasure, fostering good reading habits, developing perception and interpretation skills, offering challenges hence achievements, providing genuine communication of ideas, offering linguistic models meaningfully, developing comprehension and motivation, balancing receptive and productive skills, providing rich and diverse exposure to language, improving concentration, encouraging reflection, allowing contact with native speaker's world, improving vocabulary, syntax and structures, allowing learning from what is not taught, increasing exposure to language in a limited time leading to language acquisition

Turker (1991) states that for many students literature can provide a key to motivating them to read in English. For all students, literature is an ideal vehicle for illustrating language use and for introducing cultural assumptions. The use of literary texts in language teaching can be summarized as follows:

1. Literary texts will help not only to improve reading but listening, speaking and writing skills

2. It is possible to understand and get general information related with experiences and events in real life by using and analysing literary text

3. Literary texts will help to realize the individual and societal developments They make the readers to improve Themselves 
culturally and educationally in accordance with their emotional features. They also remove mother tongue interference

4. Literary texts make the students acquire analyzing and criticising skills

Dhillon and Mogan (2014) furthermore mention some advantages of using literature in the classroom. According to them, the use of literature is a very rich source of genuine subject matter. Literature can also encourage communication. Often, literary texts are used for critical discussion as they are rich in meaning. In addition, literature expands language awareness. In analyzing literature, students examine sophisticated or nonstandard examples of language will also make them more aware of the rules of language use. Furthermore, literature is appealing to many cultures and it is seen to be highly regarded in many communities. Students may feel proud of their achievements in understanding their readings and applying critical thinking skills. In line with this, Nina and Violeta (2012) put some benefits of using literature in language teaching. Literature is assumed to give pleasure, instill good reading practice, develop awareness and skills to analyze, offer better results in a competitive setting, provide original communication ideas, balance receptive and also productive skills, language exposure, improve the vocabulary, syntax and structure of the English language, and encourage the ability to appreciate values.

One of the literary works that can be used in teaching a language is poetry. the use of poetry as a teaching tool has also been proved by some studies. Nancy, Hadaway, and Young (2001, p. 796) state that, "poetry provides a relaxed and pleasant way to practice oral language skills". Christenson and Bassano (1995) also argued as follows:

There were important benefits to using poetry in the ESL/EFL classroom, in particular, helping develop a love of words and sounds in language learners, building a positive climate in the classroom, assisting in vocabulary development, addressing different learning styles, and providing opportunities for learners - strategy instruction.

There are many strategies of using poetry in teaching English. One of them is by asking students to write their own poems. Students can be given certain topics to be developed into poems. In this way, students may demonstrate their ability to express their ideas and imagination in the forms of poems. Students, of course, may have to pay attention to the specific characteristics of poems such as the use of theme, sound devices, rhythm, and imagery. By these strategies, students were allowed to express feelings, ideas, or opinions which then helped them to develop more ideas in writing. Students; difficulties in writing may be caused by getting stuck on ideas development. By the use of poetry to explore more ideas and feelings, students may be able to develop more ideas in writing in the forms of paragraphs.

\section{Poetry as a Form of Literature}

Poetry is one of the forms of literary work beside prose and drama. Among them, poetry has been recognized as the most imaginative form. The language in poetry will say more about feeling, ideas, or expression. In other words, poetry is more imaginative rather than informative. Wordsworth defined poetry as "the spontaneous overflow of powerful feelings, recollected in tranquility" (cited in Kennedy \& Gioia, 1995). In other words, poetry can be interpreted as the most imaginative form of literature. Poetry uses most imaginative language, full of expression of ideas, feelings, and opinions of the author.

Poetry is the most intensely emotive of literary forms. In a sense, it does all that prose can do, in developing its theme in a carefullyordered sequence of statements (Little, 1970, p. 162). As well, poetry employs the techniques of verse, making sound and formal structure 
part of its means of expression. It displays almost indefinable quality of emotional and imaginative impact. See the following example:

Tiger! Tiger! Burning bright

In the forest of the night,

What immortal hand or eye

Could frame thy fearful symmetry?

In what distant deeps or skies

Burned the fire of thine eyes?

On what wings dare he aspire?

What the hand dare seize the fire?

And what shoulder, and what art

Could twist the sinews of thy heart?

And when thy heart began to beat,

What dread hand? And dread feet?

What the hammer? What the chain?

In what furnace was the brain?

What the anvil? What dread grasp

Dare its deadly terrors clasp?

When the stars threw down their spears, And watered heaven with their tears,

Did he smile his work to see?

Did he who made the Lamb make thee?

Tiger! Tiger! Burning bright

In the forest of the night,

What immortal hand or eye,

Dare frame thy fearful symmetry?

(The Tiger by Blake, cited in Little, 1970)

Why are these, and lines like them, so remarkable in expression and effects that they are called poetry? The answer is complex, and perhaps cannot be given really satisfactorily. This is because we are dealing with imagination and emotion. But part of the answer is that poetic writing employs with particular intensity and success the methods of emotive writing (Little, 1970, pp. 162-163).

However, in analyzing the poetry, there are some aspects that are very important to understand. They are theme, imagery, sound system, and rhythm. The first aspect is theme, which concerns the use of the main ideas developed through the verse. Theme in poetry or other literary works is the basic subject. In developing the theme, the poet will be set in the "carefully ordered sequence of statements" (Little, 1970, p 162). It is further stated that the theme relates to "view of every part and aspect of it". It is about "style and placement of the item descriptions on the first page, the handling of a minor character or episode in the middle, a certain language, meaning and feeling last sentence" (Little, 1970, p. 12)

The second aspect is the use of imagery. As stated by Burns and McNamara (1983, p. $168)$, imagery is "the images produced in the mind of language". More specifically, imagery is "the presentation or description of something (idea, object, quality, animal, person, etc) by references to something else with which it becomes associated in the writer's imagination". This can be seen in the use of figurative terms that represent ideas, feelings, or opinions of the author. The language style can illustrate the imagery such as stylistic comparisons (simile, metaphor, personification, metonymy, synecdoche, hyperbola, and allusion). These are also commonly known as figures of speech. With the use of this imagery, the artistic elements of the poem can be more prominent and make it different from other languages. Examples of using imagery from the use of figure of speech can be seen in the following example:

His berd as any sowe or fox was red (The Canterbury Tales by Chaucer, cited in Burns \& McNamara, 1983, p. 168)

The poem above written by Chaucer used a figure of speech of simile, a comparison using the word like or as. As seen in the above poem, Chaucer mentioned two kinds of animals, sowe and fox to compare two different types of behaviours. Another example is as follows:

Good name in man and woman dear my lord,

Is the immediate jewel of their souls;

Who steals my purse steals trash; 'tis something, nothing;

But he that filches from me my good name Robs me of that which not enriches him 
And makes me poor indeed

(Othello by Shakespeare, cited in Burns \&

McNamara, 1983, p. 169)

The above example is a poem by Shakespeare. The poem used metaphor, one type of figures of speech, which is a comparison omitting the words like or as, so that one object is likened to another by being said to be that other. In this poem, good name is compared to a jewel. Since a jewel can be stolen, the good name can also be stolen. The words such as filches and robs were used to describe the comparison.

The third aspect of poetry is the element of sound (sound devices). The important need to be considered in this aspect is the use of the word repetition (repetition), which could make poetry more meaningful. These elements can be seen from the use of rhyme, alliteration, and assonance. Burns and McNamara (1983, p. 173) state that rhyme refers to the identical sound pattern, especially on the last line, for instance word root with the word fruit. Alliteration, which is an aspect of sound patterns in poetry, refers to the repetition of sounds in a row, while assonance is identical in sound repetition. Each element can make the sound of poetry to be more artistic, impressive, and expressive.

Another important aspect is known as rhythm. The word rhythm refers to any wavelike recurrence of motion or sound. This rhythm is secured by metre, which is used to describe the arrangement of stressed and unstressed syllables in lines. It corresponds to the beat in music (Burns \& McNamara, 1983, p. 175). One of the forms of rhythm is onomatopoeia, which is a correspondence between the sound of a word and the sound or sense denoted by the word-i.e. when the word actually imitates or echoes the sound or sense it stands for. See the following example:

The ice was here, the ice was there,

The ice was all around:

It cracked and growled, and roared and howled,

Like noises in a swound!
(The Rime of the Ancient Mariner by Mark Twain, cited in Burns \& McNamara, 1983, p. 178)

The words cracked, growled, roared, and howled are onomatopoeic words: they actually suggest the sounds of icebergs colliding and breaking up, and thus help the reader to hear what the sailor heard and to understand their fear (Burns \& McNamara, 1983, pp. 175-179).

Based on the above discussion, it can be seen that poetry occurs when the language is more imaginative, more emotionally telling. Therefore, the writer will mostly use two important devices, namely emotionally coloured words bringing strong emotional overtones or associations and sharp, sensuous, concrete language, causing the reader to experience clearly-defined mental pictures or images of what is being described. Such images may arise from plain, clear statement, or the use of the imaginative, figurative language, and can exert an influence upon the thought and feeling of the sensitive reader (Little, 1970, p. 163).

\section{METHOD}

This study was conducted at English literature program, Faculty of Language and Literature, State University of Makassar in 2016. The study focused on one class of literature class which study a course of poetry and a course of writing. The study was conducted for one semester in which the course of poetry and a course of writing were taught in the class. Two classes were involved consisting of 30 students of each. I then divided them into two groups. One class was taken as a control group taught to write without poetry writing and another class was taken as experimental group taught to write with the poetry writing.

As mentioned above, there are two main focuses in this study, namely the ability of the students to write poetry in English and the effectiveness of that poetry writing in teaching writing skills. To explore the ability of the students in making English poem, a poetry 
writing test was applied, asking students to write English poetry based on the given topics such as topics on love, friendship, family, and nature. This test was given to one of the classes which became the respondent for experimental group later. Aspects considered in the first part of this test are the theme (theme), sound (sound devices), imagery and rhythm. Students' score resulted from this test were explained descriptively to reveal the students' capabilities in creating their own poetry. The score classification is as follows

Tabel 1. Classification score of students' capabilities in creating their own poetry

\begin{tabular}{ll}
\hline Classification & scores \\
\hline Very good & $81-100$ \\
\hline Good & $61-80$ \\
\hline Poor & $41-60$ \\
\hline Very poor & $21-40$ \\
\hline
\end{tabular}

The range of the scores were 81-100 (very good) when all of the four aspects of poems were found in the students' poems. The score of 61-80 (good) was given to the poems which applied the four aspects of poems but still have minor mistakes. The scores of 41-60, categorized as poor were given to students' poems which are still missing one or two of the aspects. The last category of very poor was given to the poems of missing the four aspects.

To examine the effectiveness of the poetry created by the students as a teaching tool, especially in developing students' writing skills, a quasi-experimental design was employed. Two groups, an experimental group and a control group were employed. The first group was one experimental group, employing poetry they had written by themselves to develop their writing skills. In the treatment, the students were asked to write poetry in English. After that, they were asked to develop a paragraph based on the poetry they had created based on the given topics such as love, friendship, family, and nature. The second group was a control group taught to develop their writing skills without using poetry. The students in this group were not asked to write poems like what had been assigned in the experimental group and therefore, they were not asked to develop a paragraph based on a piece of poetry. Rather they were just given a topic and asked to develop their ideas in the form of a paragraph based on those particular topics such as love, family, friendship, and nature. The design for this study can be seen in the following diagram:

\begin{tabular}{llll} 
EG & 01 & $X$ & 02 \\
\hline CG & 01 & Y & 02
\end{tabular}

(Gay, Mills, \& Airasian, 2006, p. 258) Where

$\mathrm{EG}=$ experimental group

$\mathrm{CG}=$ Control Group

$01=$ pre-test

$02=$ post-test

$\mathrm{X}=$ treatment using poetry writing

$\mathrm{Y}=$ treatment without poetry writing

To assess the students' achievement in writing paragraph, the two groups were tested to write a paragraph before and after the treatment (pre-test and post-test). Aspects of paragraph writing assessed in this case are the content (content), organization (organization), lexicon (vocabulary), structure (structure), and punctuation (mechanics). Each aspect accounted for 20 points. Since there are five aspects to be observed, a score of 100 will be given to all of the five achieved aspects. The score range is as follows:

Table 2. Students' achievement in writing paragraph

\begin{tabular}{ll}
\hline Classification & Range of Score \\
\hline Excellent & $81-100$ \\
\hline Very Good & $61-80$ \\
\hline Good & $41-60$ \\
\hline Poor & $21-40$ \\
\hline Very Poor & $0-21$
\end{tabular}


This test serves to compare the students' skills in English writing before and after treatment using poetry writing to develop ideas in paragraphs. The results of the pre-test and post-test of both groups were then compared by looking at the average value and standard deviation. After that, the t-test significance was held by comparing the t-test and the t-value as well as the test of significance. This is to test the hypothesis $(\mathrm{H} 1$, in which poetry writing is effective in teaching writing skills and $\mathrm{H} 0$, in which poetry writing is not effective in teaching writing). If the $\mathrm{t}$-value $<\mathrm{t}$ table, it can be concluded that the $\mathrm{H} 0$ was rejected and $\mathrm{H} 1$ was accepted. If $\mathrm{H} 0$ was rejected and $\mathrm{H} 1$ was accepted, it can be concluded that poetry writing is effective in teaching writing skills.

\section{RESULTS}

This part discusses the two main findings from this study based on the two main problems formulated in this study. The first one is about the students' capability in writing poetry in English and the second one is the effectiveness of poetry writing in teaching writing skills, particularly in developing paragraphs.

\section{Students' Capability in Writing Poetry}

The main focus in this section is to reveal the students' capabilities in writing English poems. Four aspects were observed namely themes, sound devices, rhythm, and imagery. Discussion in this aspect was based on the poetry writing test given to one group of students consisting of 30 students, which later became the experimental group. Students were given a topic and asked to write poems based on the given topics. There were 30 poems resulted from this test.

The first aspect to examine from the 30 poems created by the students is about the theme. Of the 30 poems written by the students, the topic of love and affection became the priorities of respondents. One example is as follows:

Love is a simple word
But there are so many definitions about it

Everyone have their own definition of love

They said love is a verb

Love is a care

Love is love

Ah, they make me confused about that

Each person has a right to give definition

of love, isn't it?

I don't care about their definition of love

For me as I know it

Love is you

Another theme is about spirit, the future of life, natural scenery, and human relations. One of the popular topics among the students to write is a topic on friendship. One of the examples is as follows:

FRIENDSHIP

What joy it is

To have a friend like you

To giving me happiness the way you do

To giving me spirit the way you do

To giving me strength the way you do

For entertaining me up

When I'm feeling sad and down

You are putting a smile on my face everyday

Thank you so much for living there And keeping me grow

Our friendship is meant a lot for me

That I'd like to tell you

Besides the use of theme, aspect of sound devices was also observed from students' poem. The following example exemplified the poem created by the students which employed good sound devices:

I were there for a long term

In a winter

I'd never seen you that way, even for shadow

Just waiting until I tired and got weak

I were there for a long term

In a winter

I'd been waiting for your smell, even for voice

Still wait until I bored and got sick

I'm standing here a long time 
Still winter

But you'd never been there, even for a while

Then I got died, and saying goodbye!

Another aspect that was developed well in students' poems was imagery. In the poem entitled HEART below, the students demonstrated the use of imagery:

Breezy of wind stroke the trees

Wave's sound deviated the sea

Heart's soft did not listen

Heart's restless wasn't answer

Seen the sky full of shine

Bunch a dream will come true

The night change the day

But the moon closed the cloud

The use of wind, wave, sky, the moon, and the cloud personify the sense of explaining HEART, which act like human beings.

Next is about the use of rhythm. This can be seen in the following poem below:

I mired and started drowning, in the beauty of silence
Musing, thinking, recollecting, the wondrous time

The word mired and started as well as the words musing, thinking, and recollecting show onomatopoeic words showing the correspondence of the sounds of words and sense in the silence.

It can be seen that students employ all of the aspects in poetry in their own poems created by themselves. To reveal the overall capabilities of students in this poetry writing, those poems were scored under the four aspects. The range of the scores were 81-100 (very good) when all of the four aspects of poems were found in the students' poems. The score of 61-80 (good) was given to the poems which applied the four aspects of poems but still have minor mistakes. The scores of 41-60, categorized as poor were given to students' poems which are still missing one or two of the aspects. The last category of very poor was given to the poems of missing the four aspects. The range of the scores can be seen in the following table:

Table 3. Classification of Students' Capabilities in Poetry Writing

\begin{tabular}{lllll}
\hline No & Classification & scores & Frequency (f) & Percentage \% \\
\hline 1 & Very good & $81-100$ & 16 & $53.33 \%$ \\
\hline 2 & Good & $61-80$ & 8 & $26.66 \%$ \\
\hline 3 & poor & $41-60$ & 6 & $20 \%$ \\
\hline 4 & Very poor & $21-40$ & 0 & $0 \%$ \\
\hline Total & & 30 & $100 \%$ \\
\hline
\end{tabular}

From the table above, it can be seen that respondents generally had the ability to write poetry in English with good criteria. There were 16 respondents from 30 respondents $(53.33 \%)$ who got scores between 81 to 100 . These were categorized as very good. Eight respondents were categorized good for their gained score between 61 to 80 . Only 6 respondents $(20 \%)$ showed low capabilities in writing poems in English. This shows that overall, poems created by students were good category. In addition, the majority of the students $(53.33 \%)$ could produce good qualification of poetry seen from the four aspects observed, namely theme, imagery, sound devices, and rhythm.

\section{Effectiveness of Students' Poetry Writing in teaching Writing Skills}

This part discusses the second main issue in this research, that is the effectiveness of poetry writing in teaching writing, particularly in developing paragraphs. In order to see the effectiveness of this teaching strategy (using poetry writing to develop paragraphs as a part of writing skills), an experimental design was employed with two groups. As explained previously, the first group was an experimental 
group, employing poetry they had asked to write by themselves in order to develop their writing skills. In the treatment, the students were asked to write poetry in English. After that, they were asked to develop a paragraph based on the poetry they had created by them. The second group was a control group taught to develop their writing skills without using poetry. The students in this group were not asked to write poems like what had been assigned in the experimental group and therefore, they were not asked to develop a paragraph based on a piece of poetry. Rather they were just given a topic and asked to develop their ideas in the form of a paragraph based on those particular topics such as love, family, friendship, and nature.

The two samples of paragraph below demonstrate the students' capability in developing paragraph from two groups with different treatment:

Sample 1. A paragraph about love from experimental group

\begin{tabular}{ll}
\hline Poetry Created & Paragraph Developed \\
\hline Love is a simple word & In my mind, the word "love" is just a \\
But there are so many definitions about it & simple word, although I admitted that it \\
Everyone have their own definition of love & actually has many definitions. I am sure \\
They said love is a verb & that everyone in the world has different \\
Love is a care & ways of defining about love. Some \\
Love is love & which may mean to care and of course \\
& to love. Because of that, I feel confused. \\
Ah, they make me confused about that & No matter what people say about love, \\
Each person has a right to give definition of love, & I won't care. The most important thing \\
isn't it? & is that I love you my girl \\
I don't care about their definition of love & \\
For me as I know it & \\
Love is you &
\end{tabular}

In the example above (sample 1), the student wrote his poem in English first and then he was asked to develop a paragraph based on that poem. When he was given a task to develop paragraph based on that poem he wrote by himself, he could demonstrate a more precise paragraph. More ideas can be expressed since he had already expressed more ideas and feelings, or perhaps emotions in his poem before. The poem he created first assisted him to develop his ideas in paragraphs. Compare with the following example taken from a group of control group without poetry writing. The student was just given a topic of love and asked to develop a paragraph.

Sample 2. A paragraph about love from control group

Love is a need for me. I want to love someone but I am not sure she loves me or not. I don't know how to express my love. Hopefully she can understand that I love her

In the form of paragraph as seen in the above example (sample 2), a student may have restricted ideas to say. With the aspects of poetry to consider, a student may be encouraged to express ideas in the form of repetition such as repeating the word love in the first two lines of the poem, and using metaphor to express about love (love is a care, love is love, love is you).

\section{Pre-test and Post-test}

The two groups, experimental and control group, with the different treatments in teaching writing as explained above were given a test of writing before and after the treatment. The test was asking students to write a paragraph based on certain topics. The results of the pre-test of 
the two groups can be seen in the following table:

Table 4. Frequency and Percentage of Students' Writing in the pre-test of the control group

\begin{tabular}{llll}
\hline Classification & Range of Score & Frequency $(\mathrm{f})$ & Percentage $(\%)$ \\
\hline Excellent & $81-100$ & 3 & $10 \%$ \\
\hline Very Good & $61-80$ & 5 & $16.66 \%$ \\
\hline Good & $41-60$ & 10 & $33.33 \%$ \\
\hline Poor & $21-40$ & 11 & $36.66 \%$ \\
\hline Very Poor & $0-21$ & 1 & $3.33 \%$ \\
\hline Total & & 30 & 100 \\
\hline
\end{tabular}

Table 5 Frequency and Percentage of Students' Writing in the pre-test of the Experimental group

\begin{tabular}{llll}
\hline Classification & Range of Score & Frequency (f) & Percentage (\%) \\
\hline Excellent & $81-100$ & 3 & $10 \%$ \\
\hline Very Good & $61-80$ & 7 & $23.33 \%$ \\
\hline Good & $41-60$ & 10 & $33.33 \%$ \\
\hline Poor & $21-40$ & 9 & $30 \%$ \\
\hline Very Poor & $0-21$ & 1 & $3.33 \%$ \\
\hline Total & & 30 & 100 \\
\hline
\end{tabular}

In the two tables above, we can see the comparison of students' ability to write a paragraph in both groups before the treatment. It appears that the respondents in both groups had average ability in writing. Only 3 respondents from both groups that had excellent classification. Generally there were
10 people from both groups $(33.33 \%)$, which has the ability to write a paragraph with good classification.

After having the treatment, post-test was held in both groups by providing a test to write or develop paragraphs. The result can be seen in the following table:

Table 6. Frequency and Percentage of Students' Writing in the post-test of the Control group

\begin{tabular}{llll}
\hline Classification & Range of Score & Frequency $(\mathrm{f})$ & Percentage $(\%)$ \\
\hline Excellent & $81-100$ & 4 & $13.33 \%$ \\
\hline Very Good & $61-80$ & 8 & $26.66 \%$ \\
\hline Good & $41-60$ & 10 & $33.33 \%$ \\
\hline Poor & $21-40$ & 8 & $26.66 \%$ \\
\hline Very Poor & $0-21$ & 0 & $0 \%$ \\
\hline Total & & 30 & 100 \\
\hline
\end{tabular}

Table 7. Frequency and Percentage of Students' Writing in the post-test of the Experimental group

\begin{tabular}{llll}
\hline Classification & Range of Score & Frequency (f) & Percentage (\%) \\
\hline Excellent & $81-100$ & 8 & $26.66 \%$ \\
\hline Very Good & $61-80$ & 10 & $33.33 \%$ \\
\hline
\end{tabular}




\begin{tabular}{llll}
\hline Good & $41-60$ & 10 & $33.33 \%$ \\
\hline Poor & $21-40$ & 2 & $6.66 \%$ \\
\hline Very Poor & $0-21$ & 0 & 100 \\
\hline Total & & 30 & \\
\hline
\end{tabular}

From the two tables above, it can be seen the comparison of the scores gained from posttest on the students' ability to write a paragraph. It appears that the respondents in both groups have different capabilities in writing after performing treatments. A significant increase can be seen in the experimental group in which only two respondents who were in poor writing category. The others have a good, very good, and excellent classification. In the control group, the increase does not look so much.
There were 8 respondents who had poor classification (not good) in writing. There were more respondents who got excellent classification in the experimental group than in control group.

\section{Mean Score and Standard Deviation}

The following table shows the mean scores and the standard deviation from the two groups:

Table 8. Mean Score and Standard Deviation of the Experimental and Control Group

\begin{tabular}{lllll}
\hline Respondents & Control Group & \multicolumn{2}{c}{ Experimental Group } \\
\cline { 2 - 5 } & Pre-test & Post-test & Pre-test & Post-test \\
\hline Mean Score & 51.58 & 60.16 & 55.97 & 68.71 \\
\hline $\begin{array}{l}\text { Standard } \\
\text { Deviation }\end{array}$ & 18.836 & 17.724 & 18.904 & 15.967 \\
\hline
\end{tabular}

Table 8 above shows the difference in the mean scores and standard deviation of both groups. This shows that there is an increased ability to write English using methods of making poetry. The mean scores of the group taught by using methods of making poetry was higher than the mean scores the group taught by conventional methods (not using the method of making poetry).

\section{Test of Significance}

The next step is to do a test of significance by comparing the value of the t-table and $t-$ values which can be seen in the following table:

Table 9. T-test of the pre-test and post-test

\begin{tabular}{ll}
\hline $\mathrm{t}$-value & $\mathrm{t}$-table \\
\hline-1.995 & 2.000 \\
\hline
\end{tabular}

Based on the analysis above, it was found that the $t$ value was -1.995 while the $t$ table was
2.000. Because the $t$-value <t table $(-1.995$ $<2.024$ ), it can be concluded that the $\mathrm{H} 0$ was rejected and $\mathrm{H} 1$ was accepted. This means that there are differences in learning outcomes of the students who are taught by the method of using poems created by themselves to write paragraphs. Students taught to write paragraphs by using poems they had created show a significant improvement.

\section{DISCUSSION}

Findings in this study had shown two important points. The first one is about the students' capability in poetry writing. From the poetry writing test conducted to the students, it was shown that students had demonstrated good aspect of poetry in their work. As seen above, aspects such as theme, sound devices, rhythm, and imagery can be seen in some of the poems the students had written. 
The second important finding from this study is about the effectiveness of poetry writing as a teaching tool in writing skills. After conducting a treatment with a quasiexperimental design, this study found that the use of poetry writing is effective in teaching writing skills, especially in developing paragraphs. Students who were taught to write poems and asked to develop paragraph based on the poems they had written before demonstrated good ability in developing paragraph than those who were taught without poetry writing. In fact, from the poetry they had written before, students were able to acquire more ideas and able to express their opinions in the form of paragraphs.

The findings above are in line with the studies employing literary works as media in language teaching (Turker, 1991; Miccoli, 2003; Subramaniam, 2003; Sivapalan \& Subramanan, 2008; Dhillon \& Mogan, 2014). Dhillon \& Mogan (2014), for example, had mentioned that the use of literature is a very rich source of genuine subject matter. In addition, literature can encourage communication, and of course can be used for critical discussion. Dhillon and Mogan (2014) further asserts that literature teaching can motivate and facilitate students in learning and appreciating literature, although according to them, literature was also viewed as an uninteresting subject due to its structural complexity and unique use of language, which may not attract students in developing their interest towards it. Sivapalan and Subramanan (2008) in their study state that literature as "an essential and popular component of language courses in the Malaysian English Second Language", although it was found that literature was perceived as "a heavy and difficult subject" (2008, p. 64).

In terms of the use of poetry in language teaching, findings from this study also confirmed that poetry is effective in teaching language skills (Christenson \& Bassano, 1995; Ratnawati, 2009). A study by Ratnawati (2009, p. 270), for example, had found that "poetry in English teaching is effective to improve students' interest and to accumulate students' skills".

As a whole, it can be stated that poetry writing as a form of creative writing had a significant role in developing students' writing skills. This result proves the effectiveness of employing literary works as a way to teach students' writing skills, especially creative writing. Nowadays, it is suggested for teachers to employ various strategies in teaching English. Poetry, as one form of literary work proves to give high contribution to the development of English teaching strategies.

\section{CONCLUSION}

After doing this research, it can be concluded that the use of poems the students had written themselves is a good strategy to develop the writing skills. Students taught to write or develop paragraphs by using poems they had created by themselves show a significant improvement than those taught without the use of poetry writing. The study found that students with the help of poems they created are able to develop their ideas in writing.

Students also showed good capabilities in creating English poems. Of the 30 poems created by the students, it can be seen that the elements of a good poem were already seen in the poetry created by students. Aspects of poetry such as imagery, rhyme, rhythm, and sound devices can be seen in the poetry created by the students.

From these results it can be concluded that poetry as a literary form can be used as a teaching tool that can improve the effectiveness and efficiency of the English language teaching, particularly in the writing skills. The use of poems as a tool to develop paragraphs contributed a lot to the ways to enhance the creativity of the students to write. 


\section{REFERENCES}

Alter, C. \& Adkins, C. (2006). Assessing student writing proficiency in graduate schools of social work. Journal of Social Work Education, 42(2).

Burns \& McNamara. (1983). Literature: A Close Study. Australia: MacMillan Company of Australia.

Christenson, M.A., \& Bassano, S. (1995). Expanding student learning styles through poetry. In J.M. Reid (Ed.) Learning styles in the ESL/EFL classroom (pp. 96-107). Boston: Heinle \& Heinle.

Dawson, P. (2005). Creative Writing and the New Humanities. USA: Routledge.

Dhillon, K.K. \&Mogan, S. (2014). Languagebased approaches to understanding literature: A creative activity module. The English Teacher, XLIII(2), 63-78.

Gay, L.R., Mills, G.E., \& Airasian, P. (2006). Educational Research: Competencies for Analysis \& Application. Columbus: Charles E. Merrill Publishing Company.

Harmer, J. (2004). How to teach writing. England: Pearson Education Limited.

Hornby, A.S. \& Crowther, J. (1995). The Oxford Advanced Learner's dictionary. UK: Oxford University Press.

Kim, Y. \& Yoon, H. (2014). The Use of L1 as a Writing Strategy in L2 Writing Tasks. GEMA Online ® Journal of Language Studies, 14(3), 33-50.

Kennedy, X.J \& Gioia, D. (1995). Literature: An Introduction to Fiction, Poetry, and Drama $\left(6^{\text {th }} \mathrm{ed}\right)$. New York: Harper Collins Publishers.

Little. G. (1970). Approach to Literature. Australia: Science Press

Maros, M. Hua, T.K. \& Salehuddin, K. (2007). Interference in learning English: Grammatical Errors in English essay writing among rural Malay secondary school students in Malaysia. Jurnal $e$ Bangi, 2(2).
Miccoli, L. (2003). English through drama for oral skill development. ELT Journal, 57(2).

Nancy L., Hadaway, S.M.V., Young, T.A. (2001). Scaffolding Oral Language Development through Poetry for Students Learning English. The Reading Teacher, 54(8), 796-806.

Nina, D. \& Violeta, D. (2012). Why should literature be used in the Language Classroom. Procedia Social and Behavioural Sciences, 46, 1182-1186.

Ratnawati (2009). Contributions of Poetry for English Teaching. Proceeding of the ICOLE (International Conference on Language Education), Teaching And Learning Languages In Contemporary Society (pp. 262-271), 23-24 November 2009. Makassar: Language Center, State University of Makassar.

Sivapalan, S. \& Subramanian, G. (2008). The Incorporation of Literature in the English Language. 3L Language, Linguistics, and Literature, 14, 45-73

Subramaniam, G. (2003).Linguistic pathways to the study of literature in the Malaysian ESL context. GEMA Online Journal of Language Studies, 3(1).

Swander, M., Leahy, A., \& Cantrell, M. (2007). Theories of Creativity and Creative Writing Pedagogy. In S. Earnshaw. The Handbook of Creative Writing (pp. 11-23). Edinburgh: Edinburgh University Press.

Turker, F. (1991). Using "literature" in language teaching. Hacettepe Üniversitesi Ealtim Fakültesi Dergisi, 6, 299-305.

Vasque, D.A.L. (2007). Error Analysis in a written composition. Profile, 10, 135-146.

Yusof, N. (2008). E-methods in literary production: Integrating E-learning in creative writing. 3L Language, Linguistics, and Literature, 14, 127-148. 